\title{
Differential Expression of $\alpha$-Gustducin in Taste Bud Populations of the Rat and Hamster
}

\author{
John D. Boughter Jr., David W. Pumplin, Chengsi Yu, Robert C. Christy, and David V. Smith \\ Department of Anatomy and Neurobiology, University of Maryland School of Medicine, Baltimore, Maryland 21201-1509
}

The G-protein subunit $\alpha$-gustducin, which is similar to rod transducin, has been implicated in the transduction of both sweet- and bitter-tasting substances. In rodents, there are differences in sensitivity to sweet and bitter stimuli in different populations of taste buds. Rat fungiform taste buds are more responsive to salts than to sweet stimuli, whereas those on the palate respond predominantly to sweet substances. In contrast, hamster fungiform taste buds are more sensitive to sweet-tasting stimuli. Taste buds in the vallate and foliate papillae of both species are sensitive to bitter compounds. These differences in sensitivity should be reflected in the numbers of gustducin-containing cells in different taste bud populations. We examined taste buds in the rat and hamster for immunoreactivity to an antibody against $\alpha$-gustducin. Immunofluorescence of labeled taste cells was examined by confocal microscopy, and the cells were counted. Gustducin-positive cells were seen in all taste bud regions; they were spindleshaped, with circular cross-sections and apical processes that extended to the taste pore. Cells with this characteristic shape in rat vallate taste buds are Type II (light) cells. In the rat, taste buds of the fungiform papillae had fewer gustducin-positive cells $(3.1 /$ taste bud) than those of other regions, including the posterior tongue and palate ( $>8.9 /$ taste bud). Hamster fungiform taste buds contained twice as many gustducin-expressing cells (6.8/taste bud) as those of the rat. These data support the hypothesis that $\alpha$-gustducin is involved in the transduction of both sweet- and bitter-tasting stimuli by mammalian taste receptor cells.

Key words: taste receptors; gustation; fungiform papillae; vallate papilla; palate; epiglottis; $\alpha$-gustducin; G-protein; taste buds
The transduction of both sweet- and bitter-tasting substances is thought to involve membrane-bound receptors coupled to secondmessenger systems (Kinnamon and Cummings, 1992). Gustducin is an $\alpha$-subunit of a G-protein closely related to the transducins that is expressed in taste tissue (McLaughlin et al., 1992). Studies with gustducin knockout mice implicate gustducin in the detection of both sweet- and bitter-tasting compounds. In both behavioral and electrophysiological experiments, mice homozygous for the null gustducin allele were much less responsive than wild-type mice to bitter and sweet stimuli, but not to salts or acids (Wong et al., 1996).

Taste buds are specialized epithelial structures containing gustatory receptor cells. Taste buds in the rat are grouped into several populations: in fungiform papillae on the anterior portion of the tongue, in vallate and foliate papillae on the posterior tongue, in the epithelia of the nasoincisor ducts (NIDs) and "geschmacksstreifen" (GS) of the palate, and on the laryngeal surface of the epiglottis (Miller et al., 1978; Travers and Nicklas, 1990; Smith et al., 1993). These populations differ in their gustatory sensitivities, as shown by electrophysiological studies of peripheral taste fibers. In rats, chorda tympani (CT) nerve fibers innervating the fungiform papillae are most sensitive to salts and acids (Frank et al.,

\footnotetext{
Received Nov. 25, 1996; revised Jan. 27, 1997; accepted Jan. 29, 1997.

This research was supported by National Institute on Deafness and Other Communication Disorders Program Project Grant DC00347. We thank Erin Getschman for technical assistance with sectioning and microscopy, and Dr. Frank Margolis for his advice on technical matters. A portion of these results was presented at the meeting of the Society for Neuroscience, Washington D.C., November 1996.

Correspondence should be addressed to Dr. John D. Boughter Jr., Department of Anatomy and Neurobiology, University of Maryland School of Medicine, 685 West Baltimore Street, Baltimore, MD 21201-1509.

Copyright (C) 1997 Society for Neuroscience 0270-6474/97/172852-07\$05.00/0
}

1983). The greater superficial petrosal (GSP) nerve, which innervates taste buds on the palate, is most responsive to sweet-tasting stimuli (Nejad, 1986; Travers and Norgren, 1991); glossopharyngeal nerve fibers innervating the foliate and vallate taste buds respond well to acids and bitter-tasting stimuli (Frank, 1991). In contrast, fungiform taste buds of the hamster are much more sensitive to sugars than those of the rat, although like the rat they are relatively insensitive to bitter stimuli (Frank, 1973; Frank et al., 1988). Single fibers in the rat and hamster superior laryngeal nerve (SLN), which innervates taste buds of the epiglottis, respond well to water (Shingai, 1980; Smith and Hanamori, 1991) but little to sweet- or bitter-tasting compounds.

Although taste bud populations have different sensitivities, the morphology of taste buds is similar throughout the oral cavity. Taste buds contain at least two morphological cell types, the dark (Type I) and light (Type II) cells (Farbman, 1965; Kinnamon et al., 1985; Roper, 1989). Light cells are larger than dark cells, have electron-lucent cytoplasm, and are circular or oval in crosssection, with apical processes extending toward the taste pore. Dark cells have electron-dense cytoplasm and an irregular outline, with sheetlike cytoplasmic projections separating adjacent light cells (Pumplin et al., 1997). The relation between these cell types and the mechanisms of gustatory transduction is unknown.

If $\alpha$-gustducin is present in cells that transduce bitter and sweet stimuli, the number of rat taste cells expressing gustducin should be greater in both palatal and posterior tongue taste buds than in those of the anterior tongue; fungiform taste buds of the hamster should also contain more gustducin-expressing cells than those of the rat. We used immunofluorescence to quantify the distribution of gustducin-immunoreactive cells among taste buds of various regions in both rat and hamster. 


\section{MATERIALS AND METHODS}

Tissue preparation and sectioning. Thirteen adult male rats and three adult male hamsters were anesthetized with sodium pentobarbital and perfused through the left ventricle with room-temperature PBS followed by icecold $\left(4^{\circ} \mathrm{C}\right)$ fixative containing $4 \%$ formaldehyde (freshly prepared from paraformaldehyde) and $2 \%$ sucrose in $0.1 \mathrm{M}$ phosphate buffer (PB). After fixation, taste bud-bearing portions of the tongue, palate, and epiglottis were excised (see below) and stored overnight in $30 \%$ sucrose in $0.1 \mathrm{M} \mathrm{PB}$ at $4^{\circ} \mathrm{C}$. Small tissue blocks were embedded in TissueTek, frozen in isopentane $\left(-70^{\circ} \mathrm{C}\right)$, and sectioned on a cryostat.

Taste buds were obtained from rat fungiform, vallate and foliate papillae, NIDs, GS, and aryepiglottal folds, and from hamster fungiform and vallate papillae. For quantification of immunoreactive cells, we attempted where feasible to obtain both longitudinal and transverse views of the taste buds with respect to their long axis (Pumplin et al., 1997). Fungiform papillae were obtained from coronal sections of the anterior tongue, or by excising small blocks from the dorsal surface of the tongue and cutting transverse sections. Foliate papillae were obtained by excising small blocks of tongue containing the laterally located folds bearing these papillae, and cutting longitudinal or transverse sections through the taste buds. Vallate papillae were sectioned in a plane parallel to the vallate trench on the dorsal surface of the posterior tongue, or in a coronal plane perpendicular to the trench. The NID, a pyramidal projection of the anterior hard palate, was sectioned parallel to the surface of the hard palate. The GS were identified as bilateral ridges on the soft palate $\sim 1$ $\mathrm{mm}$ posterior to its junction with the hard palate; they were sectioned coronally. Lateral portions of the epiglottis, containing the aryepiglottal fold, were excised and sectioned parallel to the fold.

Antibodies. We used an affinity-purified rabbit polyclonal antibody $\left[\mathrm{G}_{\alpha}\right.$ gust (I-20); Santa Cruz Biotechnology, Santa Cruz, CA] raised against a peptide corresponding to amino acids 93-112 mapping within a highly divergent domain of rat $\alpha$-gustducin. $\mathrm{G}_{\alpha \text { gust }}$ (I-20) reacts specifically with $\alpha$-gustducin of mouse, rat, and human cell origin as shown by Western blotting and immunohistochemistry; it lacks cross-reactivity with other $\mathrm{G}_{\alpha}$ subunits, including rod or cone $\alpha$-transducin (Santa Cruz Biotechnology). Immunoreactivity to $\mathrm{G}_{\alpha}$ gust $(\mathrm{I}-20)$ was not seen in cryostat sections prepared from rat (see Fig. $1 F$ ) or hamster retina, using fixation and staining techniques described below. For comparison, we reacted taste tissue and retina to $\mathrm{G}_{\alpha \text { t1 }}(\mathrm{K}-20)$ (Santa Cruz Biotechnology), which is an affinity-purified rabbit polyclonal antibody raised against a peptide corresponding to amino acids $90-109$ of rod $\alpha$-transducin. $\mathrm{G}_{\alpha}$ t1 $(\mathrm{K}-20)$ reacts specifically with $\alpha$-transducin of mouse, rat, and human cell origin as shown by Western blotting and immunohistochemistry; it lacks cross-reactivity with $G_{\alpha+2}$ and other $\mathrm{G}_{\alpha}$ subunit proteins (Santa Cruz Biotechnology). Immunoreactivity to $\mathrm{G}_{\alpha \mathrm{t} 1}(\mathrm{~K}-20)$ was observed in the rod outer segments and outer nuclear layer in cryostat sections prepared from rat (see Fig. $1 E$ ) and hamster retina but was not seen in taste bud cells.

Immunohistochemistry. Cryostat sections $(35 \mu \mathrm{m})$ were treated with a preincubation solution of $0.3 \%$ Triton X-100, $1 \%$ bovine serum albumin, and $10 \%$ normal goat serum in PBS for $1 \mathrm{hr}$ at room temperature. Free-floating sections were then incubated overnight on a rotator with primary antibody diluted 1:100 in preincubation solution at room temperature. Immunoreacted sections were rinsed in PBS and then reacted with either fluorescein- or rhodamine-conjugated goat anti-rabbit $\mathrm{IgG}$ $(1: 100)$ for $1 \mathrm{hr}$ at room temperature; fluorescein was used when nuclei were counterstained with propidium iodide. In certain sections, nuclei were stained by exposing immunoreacted sections to propidium iodide $(0.0125 \mu \mathrm{g} / \mathrm{ml})$ for $\sim 30 \mathrm{sec}$. All stained sections were rinsed in PBS and mounted in glycerol containing $1 \%$ paraphenylenediamine for fluorescence microscopy (Johnson and Nogueira Araujo, 1981).

Control experiments used the protocol described, with the following modifications: (1) the primary antibody was omitted; (2) sections were incubated with normal rabbit serum (10\%) instead of primary antibody; and (3) primary antibody was preincubated with $\alpha$-gustducin contro peptide (3.7 $\mu \mathrm{M}$; Santa Cruz Biotechnology) for $2 \mathrm{hr}$ at room temperature. These control experiments plus a positive control (primary antibody) were conducted on coronal sections from a single rat and a single hamster vallate papilla. All three specificity controls resulted in loss of specific staining (see Fig. $2 B-D$ ).

For specificity control experiments on the retina, animals were perfused as described above, and the eyes were removed and stored overnight in $30 \%$ sucrose in $0.1 \mathrm{M} \mathrm{PB}$ at $4^{\circ} \mathrm{C}$. A small portion of the retina was peeled from the sclera, embedded in TissueTek, frozen in isopentane $\left(-70^{\circ} \mathrm{C}\right)$, and sectioned on a cryostat at $20 \mu \mathrm{m}$. Sections were mounted onto slides subbed with $0.3 \%$ chromium potassium sulfate and $1.5 \%$ gelatin, rinsed in PBS, and incubated in $0.3 \%$ Triton X-100 for 20 min. Slides were then rinsed in PBS, and the tissue was preincubated on the slide in $1 \%$ bovine serum albumin and $10 \%$ normal goat serum in PBS for $1 \mathrm{hr}$ at room temperature. Primary antibody (1:100) was applied to the sections overnight at room temperature. After they were rinsed in PBS, sections were reacted with the secondary antibody (1:100) for $1 \mathrm{hr}$ at room temperature, rinsed in PBS, and coverslipped in glycerol containing $1 \%$ paraphenylenediamine for fluorescence microscopy.

Confocal microscopy. Immunofluorescence of labeled taste bud cells was photographed with a $63 \times / 1.4$ numerical aperture (NA) lens on a Zeiss confocal laser-scanning microscope (CLSM). Using the CLSM, a series of optical sections was acquired at 1 or $3 \mu \mathrm{m}$ intervals and then combined into stereo images and/or viewed successively to count cells. The $3 \mu \mathrm{m}$ spacing gave sufficient resolution to allow cell counting yet required fewer images and less time per taste bud. Control sections were photographed with a $25 \times / 0.8$ NA objective on the CSLM. Confocal images were stored on rewritable optical disks for analysis off-line using Metamorph (Universal Imaging Corp., West Chester, PA) or the public domain program National Institutes of Health Image v. 1.59 (Wayne Rasband, National Institutes of Health, Bethesda, MD). Photomicrographs were printed on a dye-sublimation printer (Codonics, Middleburgh Heights, $\mathrm{OH}$ ). Contrast was adjusted by normal procedures on the CLSM, and the photomicrographs were printed without further alteration.

Cell quantification. Gustducin-expressing cells in each taste bud were counted from three-dimensional images that were reconstructed from the original optical sections and presented as stereo pairs. To ensure that superimposed cells were not missed in the count, taste buds with more than eight labeled cells were also quantified by observing the original optical sections in serial order. Several precautions were taken to ensure that all gustducin-expressing cells in a given taste bud were counted. Three-dimensional views showed that gustducin-expressing cells had apical processes extending to the taste pore (see Results). Thus, in longitudinal sections cells were counted only in taste buds having a visible taste pore or in which the apical processes could be seen in stereo views to converge. Cell counts were also obtained from transversely sectioned taste buds in which both cell nuclei and apical processes were visible. In taste bud populations other than those of the vallate papillae, all taste buds meeting the above criteria were imaged and counted. In the vallate papillae, we avoided imaging pieces of two superimposed taste buds; otherwise all others meeting the above criteria were included in the count. In rat fungiform taste buds, there were so few gustducin-positive cells that the nuclei were counterstained with propidium iodide to ensure that the entire taste bud was imaged.

Taste bud diameters and cell packing density. To ensure that differences in labeled cell counts were not attributable to large differences in the number of cells in taste buds in different regions, we measured the diameters of the taste buds and the packing density of cells within them, which served to estimate the relative numbers of cells in different taste bud populations. We could not simply count the number of cells per taste bud, because these $35 \mu \mathrm{m}$ sections often did not contain all of the cells within a taste bud. Three-dimensional reconstructions of rat taste buds were presented as stereo pairs by the Metamorph software. The diameter of a taste bud was measured transverse to its long axis at the widest point by tracing with the line measuring tool of the program. The diameter was taken from the outer edges of the most lateral gustducin-expressing cells and/or from boundaries of taste buds revealed by staining nuclei with propidium iodide. Boundaries seen in this fashion corresponded to boundaries visualized by labeling taste buds with $2 \mathrm{~B} 8$, an antibody that stains nearly all the cell interfaces in the taste bud but not the surrounding epithelium (Smith et al., 1993).

The cell packing density was estimated in rat taste buds in which the nuclei were stained with propidium iodide. The confocal optical section containing the maximum diameter of the taste bud was analyzed with National Institutes of Health Image using macro routines written by D.W.P. A line was drawn to enclose all the nuclear profiles of a taste bud. Profiles within this perimeter were counted, and the macro determined the number of nuclei $/ \mu \mathrm{m}^{2}$ of enclosed area.

Statistical comparisons of labeled cell number, taste bud diameter, and packing density were made between the six taste bud regions of the rat using one-way ANOVA; post hoc comparisons between regions were made using Scheffé's test for multiple comparisons (Statview, v. 4.1, Abacus Concepts, Berkeley, CA). Comparisons between rat and hamster fungiform and vallate taste buds were made with two-tailed independent $t$ tests. 


\section{RESULTS}

\section{Measures of taste buds in different regions}

We considered the possibility that any differences in the number of gustducin-positive cells in different taste bud populations could simply be attributable to variations in the total number of cells in these structures. We could not do a straightforward count of all the cells in a taste bud, because our cryostat sections $(35 \mu \mathrm{m})$ did not always include the entire taste bud. To be certain that the whole taste bud in a section was included, especially in transverse sections, the section thickness would have to be $>70 \mu \mathrm{m}$, which is too thick to be visualized completely by the $63 \times$ objective lens. To test whether the total number of cells in a taste bud section was consistent among all the regions, we measured two morphological parameters: (1) the maximum diameter of a taste bud and (2) the cell packing density within the taste bud. The maximum diameter had the advantage of being measurable in taste buds sectioned at oblique angles. Precise longitudinal or transverse sections were rare except among vallate taste buds, because most taste buds occur on folds in the epithelium and are thus oriented obliquely to the plane of section. Taste buds are flask-shaped rather than spherical or ovoid, so their total volume is not easily calculated from this maximum diameter.

Diameters were measured for 12-32 taste buds in each taste bud-bearing region of the rat. There was a significant effect of region on the diameter of the taste buds (ANOVA; $F_{(5,110)}=$ 4.18; $p<0.005)$. As shown in Figure $1 A$, the mean maximum diameter of fungiform taste buds was slightly larger than that of taste buds in all other regions except the epiglottis (Scheffé's test; $p<0.05)$. Because fungiform taste buds were not smaller than those of other regions, taste bud size cannot account for the smaller number of gustducin-containing cells in the fungiform taste buds of the rat (see below).

To further ensure that our results did not simply reflect anatomical differences in the taste buds, we examined the number of cells per unit area within a taste bud section. Nuclei were labeled with propidium iodide, and the number of nuclear profiles $/ \mu \mathrm{m}^{2}$ was acquired from sections through the middle of each taste bud. Within a taste bud section, the packing density of nuclei appears to be the same in all directions; therefore this measure can be used on taste buds viewed at various angles. Packing density was measured in 12-17 taste buds in each population. As shown in Figure 1, the packing density did not vary significantly among these regions (ANOVA; $F_{(5,81)}=1.812 ; p=0.120$ ), consistent with the hypothesis that the number of cells was about the same in all taste buds.

\section{$\alpha$-Gustducin in rat and hamster taste bud cells}

Gustducin expression was observed in cells of rat and hamster taste buds but not in those of the surrounding epithelium. Gustducin-immunoreactive cells in the rat vallate papilla are depicted in the low-power photomicrograph of Figure $2 A$, which shows a single optical section through an entire vallate trench. Several spindle-shaped cells in each taste bud on both sides of the trench expressed gustducin; however, when the primary antibody was omitted (Fig. $2 B$ ) there was no immunoreactivity. When $10 \%$ normal rabbit serum was substituted for the primary antibody (Fig. $2 C$ ) or when the antibody was preincubated with control peptide (Fig. 2D), there was also no labeling. Similar results were found with these conditions in sections through the hamster vallate papilla (data not shown). Control sections through the rat retina are also shown in Figure 2. The rod outer segments and the outer nuclear layer of the retina were immunoreactive to the
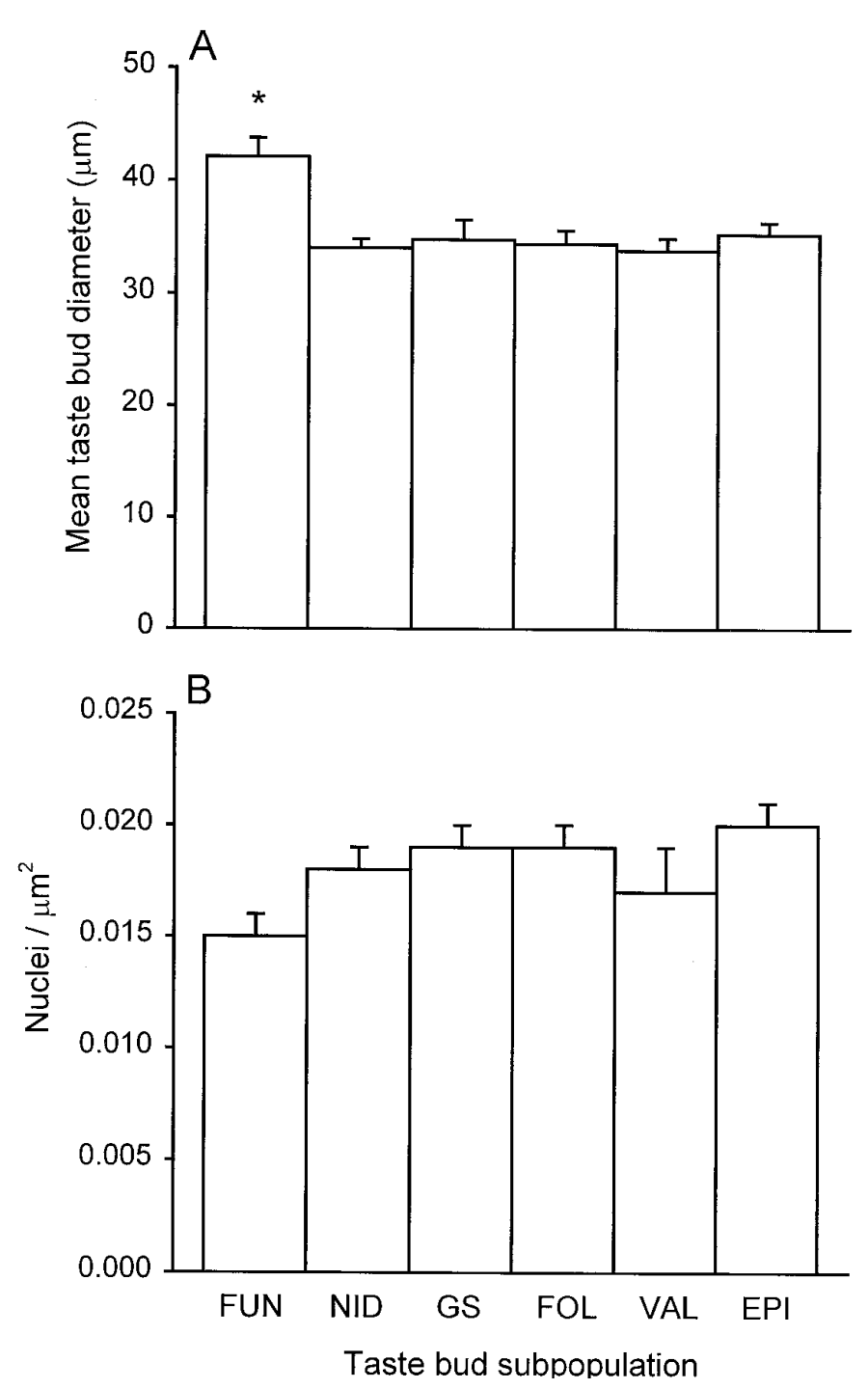

Figure 1. A, Mean (+ SEM) diameters of taste buds from each taste bud-bearing region in the rat. Fungiform taste buds were significantly wider than those in other regions (asterisk; see Results for details). $B$, Mean ( + SEM) packing density (nuclei $/ \mu \mathrm{m}^{2}$ ) of nuclei in taste buds from each taste bud-bearing region in the rat. There was no significant difference among these taste bud populations (see Results).

$\alpha$-transducin antibody (Fig. $2 E$ ) but not to the antibody against $\alpha$-gustducin (Fig. $2 F$ ).

Cells expressing gustducin were found in taste buds from all six regions examined in the rat (Fig. 3) and the two investigated in the hamster (Fig. 4). Gustducin-positive cells had a similar morphology in all regions. Labeled cells had a central enlarged portion containing the nucleus and processes extending toward the apical taste pore and the basal portion of the taste bud. Stereoscopic images showed that these processes, as well as the central portion of the cell, were round to slightly oval in cross-section. Taste bud cells of the rat vallate papilla having this characteristic shape were shown to be light (Type II) cells (Pumplin et al., 1997), although such differences in shape between dark and light cells have not been quantitatively established for taste buds in other regions.

There were fewer cells expressing gustducin in the rat fungiform papillae (Fig. 3A) than in other areas (see below). The single labeled cell in Figure $3 A$ is shown amid nuclei that have been counterstained with propidium iodide, making the structure of the 

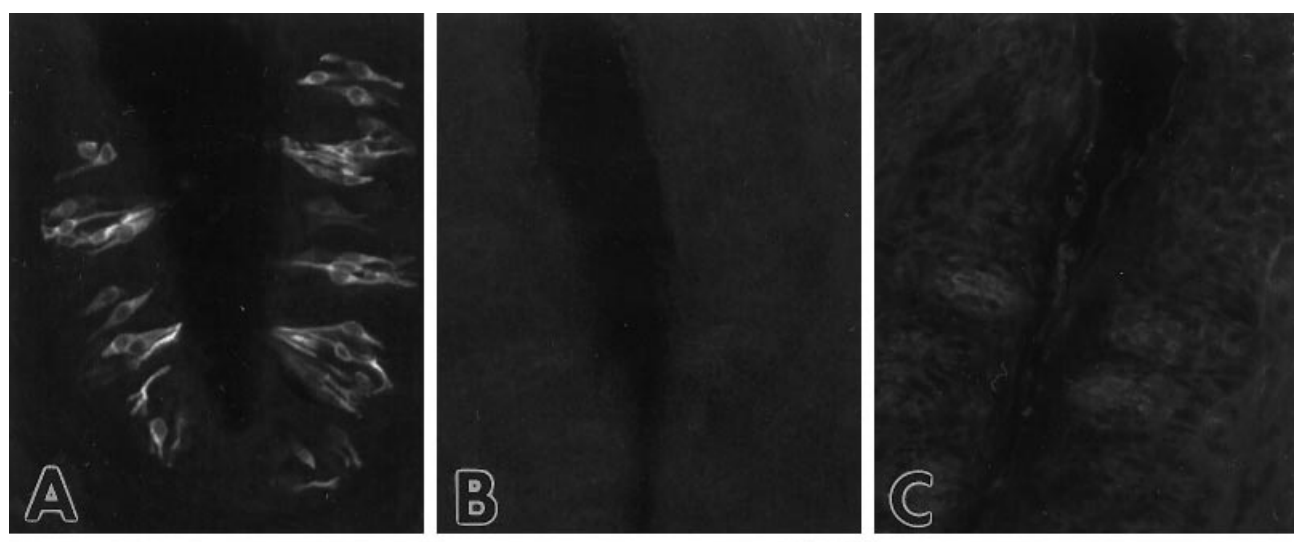

Figure 2. Photomicrographs of indirect immunofluorescence in coronal sections through one trench of a single rat vallate papilla $(A-D)$ and transverse sections through the rat retina $(E, F)$. These images are single optical sections acquired using the CLSM. $A$, Vallate taste cells immunoreactive for $\alpha$-gustducin. Individual spindle-shaped gustducin-positive cells can be seen in many taste buds surrounding the vallate trench. No immunoreactivity was observed in the vallate taste buds in sections reacted with the primary antibody omitted $(B)$, with $10 \%$ normal rabbit serum substituted for the primary antibody $(C)$, or after the $\alpha$-gustducin antibody has been preincubated for $2 \mathrm{hr}$ with control peptide $(D)$. Rod outer segments and the outer nuclear layer of the retina were immunoreactive for $\alpha$-transducin $(E)$ but not for $\alpha$-gustducin $(F)$. Scale bar (shown in $F$ ): $100 \mu \mathrm{m}$.
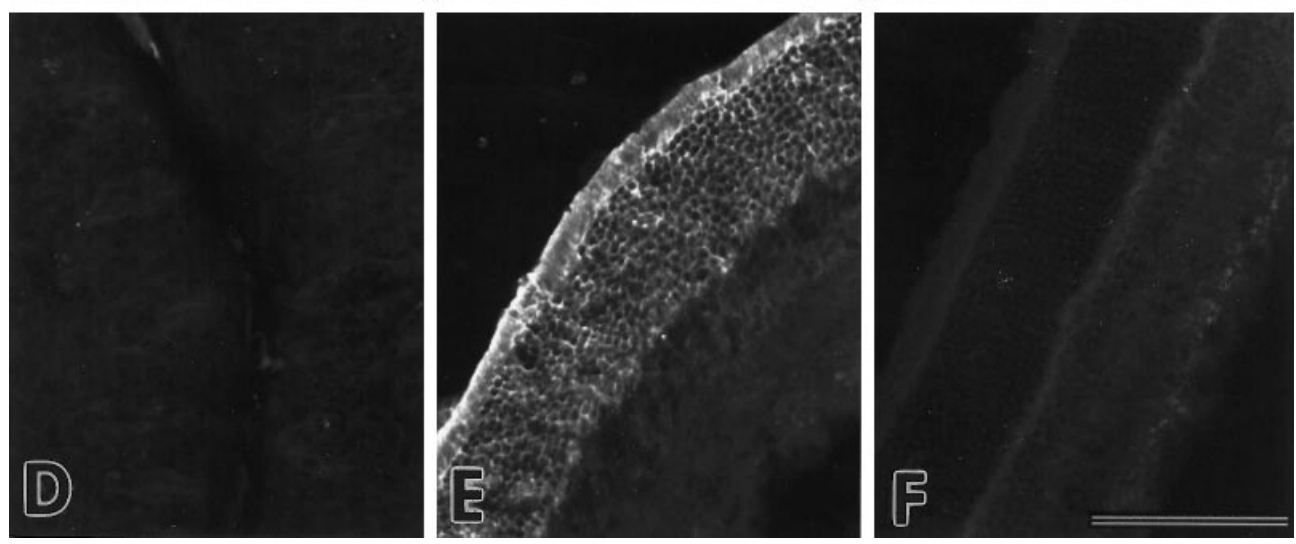

taste bud apparent. This cell is spindle-shaped; its apical process extends toward the taste pore. In this and the other panels of Figures 3 and 4, the taste pore is located toward the top or the top right of the photomicrograph. A labeled taste bud from the NID of the rat is shown in Figure $3 B$. This taste bud was cut at an oblique angle, which shows the cross-sectional shape of many of the cells and also reveals the apical projections of some. As in the NID, taste buds of the GS also contain many gustducin-positive cells (Fig. 3C). The numerous taste bud cells that are gustducinpositive in the rat foliate and vallate papillae are shown in Figure 3, $D$ and $E$, respectively. There are two foliate taste buds evident in Figure $3 D$. Taste buds of the rat epiglottis also contain gustducin-immunoreactive cells (Fig. $3 F$ ). These cells, like those in other regions, converged at the taste pore.

Taste buds of the hamster fungiform and vallate papillae are shown in Figure 4, $A$ and $B$, respectively. Taste bud cells in both of these regions were immunoreactive for gustducin, and those in the fungiform papillae (Fig. $4 A$ ) were more numerous than in the rat (compare Fig. $3 A$ ), as described below.

\section{Relative expression of gustducin across taste bud populations}

Visual inspection of taste buds from the various regions suggested that fungiform taste buds in the rat had fewer gustducinexpressing cells than did those in other regions (Fig. 3). We verified this impression by counting gustducin-positive cells in taste buds obtained from all six regions. Cells were counted in 52 fungiform, 67 NID, 52 GS, 36 foliate, 97 vallate, and 29 epiglottal taste buds of the rat (open bars, Fig. 5). The number of gustducinpositive cells was significantly different among these six taste bud populations (ANOVA; $F_{(5,327)}=41.88 ; p<0.0001$ ). As shown in Figure 5, rat fungiform taste buds had fewer gustducin-expressing cells $($ mean $=3.12 ;$ SEM $=0.27)$ than any other region (Scheffé's test; $p<0.05)$. The numbers of gustducin-expressing cells in the other regions were greater and nearly equal, with $9.30 \pm 0.43$ in the NID, $9.56 \pm 0.40$ in the GS, $8.97 \pm 0.41$ in the foliate, and $9.81 \pm 0.32$ in the vallate taste buds. Taste buds of the epiglottis also had significantly fewer gustducin-expressing cells (6.72 \pm 0.59 ) than these other regions, except the foliate papillae (Scheffé's test; $p<0.05)$.

The striped bars in Figure 5 show the mean number of gustducinpositive cells in fungiform and vallate taste buds of the hamster. Cells were counted in 20 fungiform and 11 vallate taste buds in hamsters. Hamster fungiform taste buds had significantly more gustducinexpressing cells $(6.80 \pm 0.44)$ than did those of the rat (two-tailed independent $t$ test; $t=7.12$; df $=70 ; p<0.0001)$. In contrast, vallate taste buds from the two species did not differ significantly in numbers of gustducin-expressing cells $(t=0.539$; $\mathrm{df}=106$; $p=0.59)$; however, hamster vallate taste buds did have significantly more gustducin-positive cells $(9.27 \pm 0.85)$ than hamster fungiform taste buds $(t=2.846$; df $=106 ; p<0.01)$.

\section{DISCUSSION}

Both behavioral and electrophysiological studies with $\alpha$-gustducin knockout mice strongly implicate this G-protein subunit in the transduction of both bitter- and sweet-tasting substances (Wong et al., 1996), although its mechanisms of action in these separate events are not yet understood (Kinnamon, 1996; Lindemann, 1996). In support of a role for $\alpha$-gustducin in sweet and bitter taste, we show that there are fewer gustducin-expressing cells in taste buds of the rat's fungiform papillae that are relatively less sensitive to sweet or bitter stimuli (Frank et al., 1983) than those in the foliate or vallate papillae (Frank, 1991). Moreover, taste buds of the rat's palate, which are highly sensitive to sweet-tasting but not bitter-tasting compounds (Nejad, 1986; Travers and 

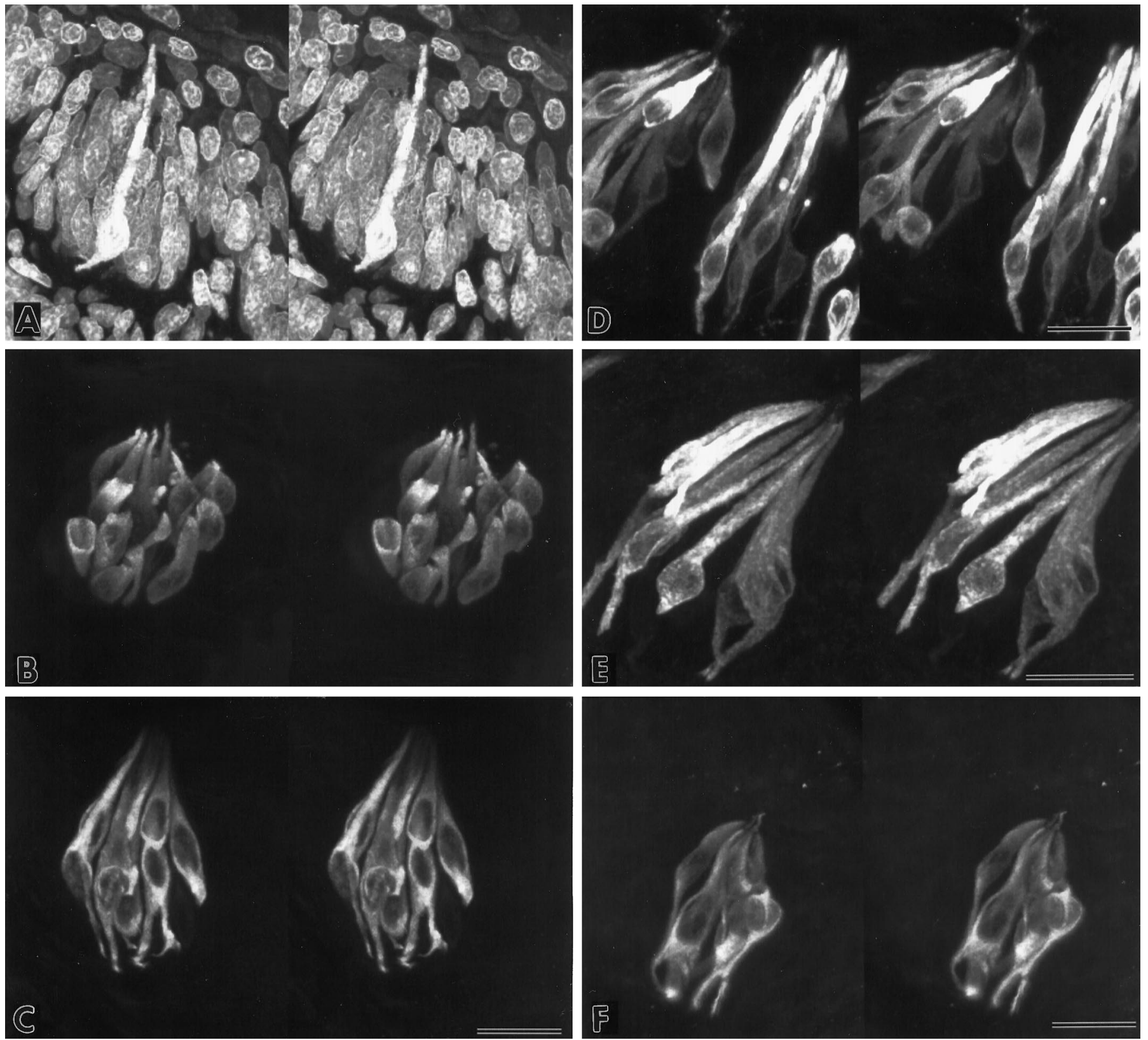

Figure 3. Stereoscopic views of indirect immunofluorescence of $\alpha$-gustducin labeling in different subpopulations of rat taste buds: fungiform $(A)$, NID $(B)$, GS $(C)$, foliate $(D)$, vallate $(E)$, and epiglottis $(F)$. All views were reconstructed from 1- or 3- $\mu$ m-thick optical sections taken with the CLSM. All images are of a single taste bud except the foliate $(D)$, where most of two taste buds can be seen. The plane of orientation is longitudinal to the long axis of the taste bud except for the NID $(B)$, which is somewhat oblique. Propidium iodide was used to stain nuclei in the fungiform taste bud $(A)$; a single elongated gustducin-positive cell can be seen in the center of this taste bud. In the taste buds from other regions, many gustducin-positive cells are evident. The taste pore is toward the top in each photomicrograph. Gustducin appears to be distributed throughout the cytoplasm of the taste cells, which have a characteristic spindle shape. Scale bars, $20 \mu \mathrm{m}$; same in $A, B$, and $C$.

Norgren, 1991), show extensive gustducin labeling (Fig. 5, NID and $G S$ ). Taken together, these data show that many taste cells in regions responsive to either sweet or bitter stimuli express this gustatory G-protein but that this transduction component occurs in significantly fewer cells in taste buds that are much less responsive to these two classes of stimuli.

Gustducin expression has been demonstrated previously in fungiform, foliate, and vallate taste buds of the rat (McLaughlin et al., 1992), although differences among these taste buds were not quantified. We now show that gustducin-expressing cells are also present in taste buds from two palatal regions (NID and GS), in numbers similar to those of vallate and foliate taste buds. The GSP nerve, which innervates palatal taste buds, is much more responsive to sucrose and other sweet-tasting compounds than the CT nerve, which innervates fungiform taste buds (Nejad, 1986). Behavioral experiments show that the GSP plays a critical role in the responsiveness of the rat to sweet-tasting substances. Bilateral section of the GSP disrupts the rat's licking response to sucrose (Krimm et al., 1987). The large number of gustducin-positive cells in the palatal taste buds (Fig. 5, NID and GS), which are relatively insensitive to bitter stimuli (Nejad, 1986), further implicates $\alpha$-gustducin in the transduction of sweet-tasting substances. 

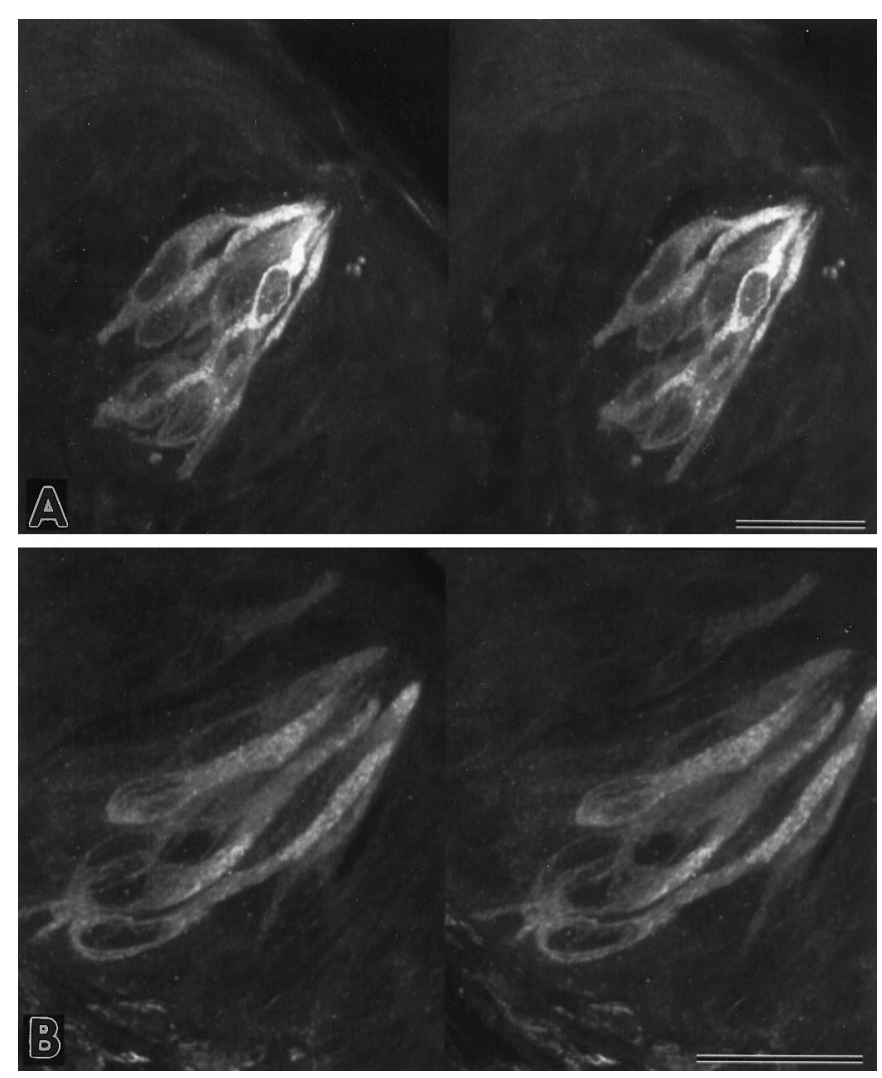

Figure 4. Stereoscopic views of indirect immunofluorescence of $\alpha$-gustducin labeling in fungiform $(A)$ and vallate $(B)$ taste buds of the hamster. Many gustducin-positive cells are seen in both taste buds. Scale bars, $20 \mu \mathrm{m}$.

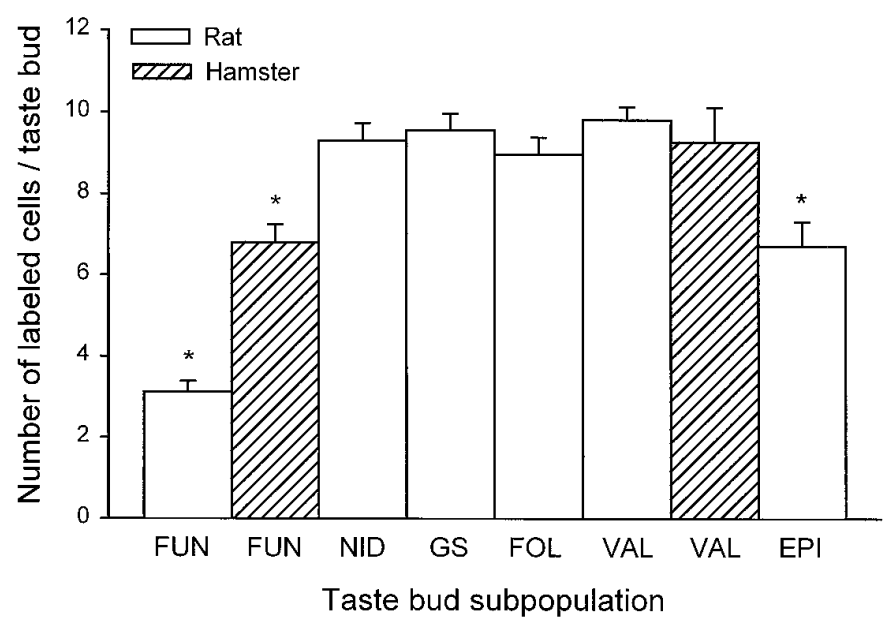

Figure 5. Mean (+ SEM) number of gustducin-immunoreactive cells for the six taste bud regions in the rat (open bars) and for fungiform and vallate taste buds in the hamster (striped bars). FUN, Fungiform; NID, nasoincisor ducts; $G S$, geschmacksstreifen; $F O L$, foliate; $V A L$, vallate; EPI, epiglottis. Asterisks indicate significant differences (for details, see Results).

Hamster fungiform taste buds contained significantly more gustducin-positive cells than did those of the rat (Fig. 5). This finding corresponds to what is known about the relative sensitivities of the anterior tongue in both species. The CT nerve of both rat and hamster responds well to salts and acids but poorly to bitter stimuli (Smith and Marui, 1989). The hamster CT, however, responds well to sucrose and other sweet-tasting stimuli (Frank, 1973; Frank et al., 1988), but the rat CT does not (Frank et al., 1983). Of $40 \mathrm{CT}$ fibers in the hamster, $25 \%$ were classified as "sucrose-best," meaning that they responded more to sucrose than to stimuli representing the other basic taste qualities. In contrast, only 4 of 44 single fibers in the rat CT were sucrose-best (Frank et al., 1983). The greater number of gustducin-positive cells in hamster fungiform papillae compared with those of the rat (Fig. 5) further implicates $\alpha$-gustducin in the transduction of sweet stimuli.

Gustducin expression was also evident in taste buds of the rat epiglottis. Mammalian epiglottal taste buds are predominantly responsive to water (Stedman et al., 1980; Shingai and Beidler, 1985; Smith and Hanamori, 1991). Although fibers in the SLN of the hamster respond most strongly to water, $\mathrm{NaCl}$, or $\mathrm{HCl}$, they do show small responses to sucrose and quinine hydrochloride. Comparable single-fiber data are not available on the rat SLN. The mechanism of water detection by epiglottal taste cells is not known, but previous studies have implicated an outward flow of $\mathrm{Cl}^{-}$ions (Cohen et al., 1955; Shingai, 1977). There is no evidence to date that water transduction involves a G-protein-coupled membrane receptor, but the slight sensitivity to sucrose or quinine could possibly account for the $\alpha$-gustducin expression of laryngeal taste bud cells.

Gustducin-positive cells were spindle-shaped, with round thin processes extending toward the taste pore. In vallate taste buds, cells with this shape are light (Type II) cells (Pumplin et al., 1997). Light cells are easily distinguished from dark (Type I) cells by their larger size, their round shape, and their lack of the lateral cytoplasmic projections that characterize dark cells. Previous electron microscopic observations have also suggested that gustducin is expressed by light cells in the rat vallate papilla (Tabata et al., 1995). Because gustducin has been implicated in the transduction of sweet- and bitter-tasting substances (Wong et al., 1996), these data strongly suggest that light cells are taste receptor cells; however, there is evidence to show that gustducin is not present in all light cells. In rat vallate taste buds, the A blood group antigen is also expressed by many light cells, and there is only partial overlap between these cells and those that are gustducin-positive (Pumplin et al., 1996). Thus gustducin is expressed by a subset of light cells.

Taste cells arise from surrounding epithelial cells that migrate into the taste bud and then differentiate (Beidler and Smallman, 1965; Farbman, 1980). In our studies, gustducin labeling in a sectioned taste bud cell invariably extended into any portion of its apical or basal process that was present in the section. Thus, expression of gustducin must be turned on only after the taste bud cell has developed the extended apical and basal processes characteristic of a morphologically mature cell. Because the life span of taste bud cells in fungiform papillae (Beidler and Smallman, $1965)$ is approximately the same as that of cells in the vallate papilla (Farbman, 1980), the cells should be morphologically mature for the same amount of time in both regions; however, we find significantly fewer cells expressing gustducin in fungiform papillae. Thus gustducin is not likely to be a simple marker of maturity that is expressed only during a portion of the lifetime of every taste cell. Instead, gustducin expression must be controlled separately so that it is turned on only in some light cells. Moreover, the relative number of light cells that express gustducin is correlated with the sensitivity to bitter and sweet stimuli in these populations. Taken together, these findings suggest that light cells 
expressing gustducin are the receptor cells for these stimuli. Other light cells, without gustducin expression, may respond only to salts or acids; the transduction of these stimuli does not involve G-protein-coupled receptors (Kinnamon and Cummings, 1992).

Gustducin expression as seen by immunofluorescence occurred throughout the cytoplasm and was not preferentially concentrated at the plasma membrane (Fig. 3). In this respect, gustducin is unlike the G-proteins $G_{s}, G_{i}$, and $G_{o}$, which are bound to membranes and require detergent for solubilization (Gilman, 1987). $\alpha$-Gustducin, however, is similar in sequence to $\alpha$-transducin found in vertebrate rods (McLaughlin et al., 1992). Transducin can be eluted from rods with GTP or nonhydrolyzable triphosphate analogs without the use of detergent (Kuhn, 1980). Thus, the activated form of transducin is soluble and may be distributed within the cytoplasm, as suggested by the immunofluorescence seen in the outer nuclear layer of the retina (Fig. 2E). Although it is assumed that G-proteins are associated with the inner surface of the plasma membrane (Gilman, 1987), immunofluorescent studies of both gustducin (Fig. 3) and transducin (Ruiz-Avila et al., 1995) suggest that these G-proteins are widely distributed within the cytoplasm of taste bud cells.

\section{REFERENCES}

Beidler LM, Smallman R (1965) Renewal of cells within taste buds. J Cell Biol 27:263-272.

Cohen MJ, Hagiwara S, Zotterman Y (1955) The response spectrum of taste fibers in the cat: a single fiber analysis. Acta Physiol Scand $33: 316-332$

Farbman AI (1965) Fine structure of the taste bud. J Ultrastruct Res 12:328-350.

Farbman AI (1980) Renewal of taste bud cells in rat circumvallate papillae. Cell Tissue Kinet 13:349-357.

Frank ME (1973) An analysis of hamster afferent taste nerve response functions. J Gen Physiol 61:588-618.

Frank ME (1991) Taste-responsive neurons of the glossopharyngeal nerve of the rat. J Neurophysiol 65:1452-1463.

Frank ME, Contreras RJ, Hettinger TP (1983) Nerve fiber sensitivities to ionic taste stimuli in chorda tympani of the rat. J Neurophysiol 50:941-960.

Frank ME, Bieber SL, Smith DV (1988) The organization of taste sensibilities in hamster chorda tympani nerve fibers. J Gen Physiol 91:861-896.

Gilman AG (1987) G proteins: transducers of receptor-generated signals. Annu Rev Biochem 56:615-649.

Johnson GD, Nogueira Araujo GM (1981) A simple method of reducing the fading of immunofluorescence during microscopy. J Immunol Methods 43:349-350.

Kinnamon SC (1996) A bitter-sweet beginning. Nature 381:737-738.

Kinnamon SC, Cummings TA (1992) Chemosensory transduction mechanisms in taste. Annu Rev Physiol 54:715-731.

Kinnamon JC, Taylor BJ, Delay RJ, Roper SD (1985) Ultrastructure of mouse vallate taste buds. I. Taste cells and their associated synapses. J Comp Neurol 235:48-60.
Krimm RF, Nejad MS, Smith JC, Miller IJ, Beidler LM (1987) The effect of bilateral sectioning of the chorda tympani and the greater superficial petrosal nerves on the sweet taste in the rat. Physiol Behav 41:495-501.

Kuhn H (1980) Light- and GTP-regulated interaction of GTPase and other proteins with bovine photoreceptor membranes. Nature 283:587-589.

Lindemann B (1996) Chemoreception: tasting the sweet and the bitter. Curr Biol 6:1234-1237.

McLaughlin SK, McKinnon PJ, Margolskee RF (1992) Gustducin is a taste-cell-specific $\mathrm{G}$ protein closely related to the transducins. Nature 357:563-569.

Miller IJ, Gomez MM, Lubarsky EH (1978) Distribution of the facial nerve to taste receptors in the rat. Chem Sens Flav 3:397-411.

Nejad MS (1986) The neural activities of the greater superficial petrosal nerve of the rat in response to chemical stimulation of the palate. Chem Senses 11:283-293.

Pumplin DW, Yu C, Boughter JD, Smith DV (1996) Relationships of cell-surface markers to gustducin expression in taste bud cells. Soc Neurosci Abstr 22:1827A.

Pumplin DW, Yu C, Smith DV (1997) Light and dark cells of rat vallate taste buds are morphologically distinct cell types. J Comp Neurol 378:389-410.

Roper SD (1989) The cell biology of vertebrate taste receptors. Annu Rev Neurosci 12:329-353.

Ruiz-Avila L, McLaughlin SK, Wildman D, McKinnon PJ, Robichon A, Spickofsky N, Margolskee RF (1995) Coupling of bitter receptor to phosphodiesterase through transducin in taste receptor cells. Nature 376:80-85.

Shingai T (1977) Ionic mechanism of water receptors in the laryngeal mucosa of the rabbit. Jpn J Physiol 27:27-42.

Shingai T (1980) Water fibers in the superior laryngeal nerve of the rat. Jpn J Physiol 30:305-307.

Shingai T, Beidler LM (1985) Response characteristics of three taste nerves in mice. Brain Res 335:245-249.

Smith DV, Hanamori T (1991) Organization of gustatory sensitivities in hamster superior laryngeal nerve fibers. J Neurophysiol 65:1098-1114.

Smith DV, Marui T (1989) Brainstem mechanisms of gustation. In: Neural mechanisms in taste (Cagan RH, ed), pp 179-195. Boca Raton, FL: CRC.

Smith DV, Akeson RA, Shipley MT (1993) NCAM expression by subsets of taste cells is dependent upon innervation. J Comp Neurol 336:493-506.

Stedman H, Bradley R, Mistretta C, Bradley B (1980) Chemosensitive responses from the cat epiglottis. Chem Senses 5:233-245.

Tabata S, Crowley HH, Böttger B, Finger TE, Margolskee RF, Kinnamon JC (1995) Immunoelectron microscopic analysis of gustducin in taste cells. Chem Senses 20:788A.

Travers SP, Nicklas K (1990) Taste bud distribution in the rat pharynx and larynx. Anat Rec 227:373-379.

Travers SP, Norgren R (1991) Coding the sweet taste in the nucleus of the solitary tract: differential roles for anterior tongue and nasoincisor duct gustatory receptors in the rat. J Neurophysiol 65:1372-1380.

Wong GT, Gannon KS, Margolskee RF (1996) Transduction of bitter and sweet taste by gustducin. Nature 381:796-800. 